\title{
Identification and analysis of vocal communication pathways in birds through inducible gene expression
}

\author{
CLAUDIO V. MELLO \\ Neurological Sciences Institute, Oregon Health and Science University \\ 505 NW 185th Avenue, Beaverton, OR 97006, USA \\ Manuscript received on January 15, 2004; accepted for publication on February 5, 2004.

\begin{abstract}
The immediate-early gene zenk is an activity-dependent gene highly induced in auditory processing or vocal motor control brain areas when birds engage in hearing or producing song, respectively. Studies of the expression of zenk in songbirds and other avian groups will be reviewed here briefly, with a focus on how this analysis has generated new insights on the brain pathways and mechanisms involved in perceptual and motor aspects of vocal communication and vocal learning.
\end{abstract}

Key words: zenk, songbird, auditory, learning, birdsong.

\section{INTRODUCTION}

Activity-dependent genes are genes whose expression is induced in the brain when neuronal circuits are activated by various stimuli or behaviors (Morgan and Curran 1989, Sheng and Greenberg 1990). Analysis of the expression of inducible genes has, thus, been very useful to map the brain areas associated with specific stimuli or behaviors (Kaczmarek and Robertson 2002). The immediate-early gene zenk (a.k.a. zif-268, NGFI-A, egr-1 or Krox-24) is highly induced in discrete areas of the avian brain when birds hear song (Mello et al. 1992, Mello and Clayton 1994), or when they engage in singing behavior (Jarvis and Nottebohm 1997). Studies on the regulation of zenk have yielded high-resolution maps of brain activation associated with perceptual and motor aspects of vocal communication in songbirds and other avian groups. As discussed in detail elsewhere (Kaczmarek and Robertson 2002), zenk and some other inducible genes have been linked

E-mail: melloc@ohsu.edu to synaptic plasticity and some forms of long-term memory in rodents (Guzowski et al. 2000, Jones et al. 2001). Therefore, the brain areas revealed by zenk expression analysis in birds are likely associated with neuronal plasticity and may be involved in long-term memory formation and/or storage (Mello 1998).

\section{ZENK INDUCTION BY HEARING BIRDSONG}

Zenk induction by hearing song occurs in the auditory nucleus of the midbrain, as well as in several discrete areas in the caudomedial telencephalon (Mello and Clayton 1994). Tract-tracing studies have revealed that areas showing song-induced zenk expression are interconnected and are part of a complex circuitry that arguably constitutes the central auditory processing pathways in the avian brain (Mello et al. 1998, Vates et al. 1996). The zenk response to song in these areas occurs in both sexes and is present in both avian vocal learners (avian orders where song is learned, usually from a parent or tutor, i.e. songbirds, parrots and humming- 
birds) and vocal non-learners such as doves and chicks (Jarvis et al. 2000, Jarvis and Mello unpubl. obs.). Electrophysiological recordings have confirmed that areas revealed by zenk expression respond to song auditory stimulation (Chew et al. 1995, Stripling et al. 1997). Importantly, in songbirds, the areas revealed by song-induced zenk expression exclude the song control system (Jarvis and Nottebohm 1997, Mello and Clayton 1994), i.e. a set of interconnected brain areas known to be involved in birdsong production and several aspects of song learning (see reviews in Brenowitz et al. 1997). Thus, a complex auditory system distinct from the song control system is activated by birdsong and appears to play an important role in birdsong auditory processing (Mello 2002).

The area that shows the most prominent induction of zenk is the caudomedial nidopallium (NCM), an area that is likely analogous to supragranular layers of the mammalian auditory cortex (Karten and Shimizu 1989, Mello et al. 1998). Zenk induction in NCM is rapid and transient, and apparently reflects a tuning of neuronal units in NCM to features present in conspecific song (Mello et al. 1992). Furthermore, the topographical distribution of the zenk response within NCM depends on acoustic features present in the song stimulus, as has been most clearly revealed by analyzing zenk expression in the Domestic Canary Serinus canaria (Waterslager strain) NCM in response to the presentation of various classes of canary song syllables (Ribeiro et al. 1998). Interestingly, the electrophysiological responses of NCM neurons to song decrease rapidly upon repeated presentations of the same song stimulus (Chew et al. 1995). This "habituation" is songspecific and long-lasting, and its maintenance depends on gene expression in NCM during discrete time windows that follow the song presentation period. The habituation of NCM neurons may, therefore, represent a mechanism that contributes to the laying-down of long-lasting song auditory memories. Song-induced zenk expression occurs during the time window of required gene expression for long-term habituation, and thus zenk could be in- volved in this long-term plasticity, but this possibility remains to be tested directly. Further evidence implicating NCM and its associated zenk response in the formation and/or long-term maintenance of song auditory memories derives from studies on the ontogeny of the zenk response to song (Jin and Clayton 1997), and from the discovery that zenk expression in the NCM of adults in response to a tutor song correlates with the degree to which the birds copied that song during the song learning period (Bolhuis et al. 2000). Long-lasting song auditory memories mediated by NCM and other auditory processing areas may play a prominent role in processes such as individual recognition, mate selection and vocal learning (Mello 1998).

\section{ZENK INDUCTION BY SINGING}

In contrast to hearing song, zenk is highly induced in the nuclei that constitute the song control system when songbirds engage in active singing behavior (Jarvis and Nottebohm 1997). This system can be subdivided into a direct motor pathway, required for singing behavior, and an anterior forebrain pathway, which has been implicated in song learning (Brenowitz et al. 1997). Zenk expression in song control nuclei is associated with the motor action of singing, as it occurs even in deafened birds, where auditory feedback is absent (Jarvis and Nottebohm 1997). Furthermore, zenk expression by singing also occurs in nuclei of the anterior pathway, which was originally thought not to participate in singing behavior in adults (Bottjer et al. 1984, Scharff and Nottebohm 1991). The zenk expression data, however, provides clear evidence for the activation of anterior forebrain song nuclei when birds sing, indicating that this pathway is also involved in the neural control of singing behavior. Since zenk expression in the anterior pathway is context dependent (Jarvis et al. 1998), this pathway may participate in coordinating song with other behaviors related to the specific behavioral context of singing.

The zenk induction patterns associated with hearing and producing birdsong occur in freeranging birds within their natural habitat, as 
has been demonstrated in Song Sparrows Melospiza melodia using a song playback challenge paradigm (Jarvis et al. 1997). Thus, brain gene regulation in association with birdsong is not just a laboratory finding, but actually occurs in birds in their natural setting. Zenk regulation by song has also been used to identify and characterize auditory and vocal control brain areas in parrots and hummingbirds, the only vocal learning birds besides songbirds. The analysis in the Budgerigar Melopsittacus undulatus (Psittacidae) has revealed new details on the morphology of vocal control areas previously identified by tract-tracing methods, as well as some previously unidentified vocal nuclei (Jarvis and Mello 2000). In hummingbirds, the zenk expression maps constitute a first demonstration of the occurrence of telencephalic vocal control nuclei in this avian order, further substantiating the link between the occurrence of such nuclei and vocal learning (Jarvis et al. 2000). This comparative approach has revealed striking similarities in auditory and vocal control pathways in all vocal learning birds, indicating that these pathways evolved under strong evolutionary constraints in vocal learning avian orders. Most importantly, it has become clear that all vocal learning groups evolved a set of nuclei (including both pallial and striatal areas) that are dedicated to the motor control of learned vocalizations. Current studies are evaluating whether telencephalic vocal control areas might also be present in species representative of avian orders that did not evolve vocal learning, including doves and sub-oscines.

\section{CONCLUSIONS}

In summary, analysis of song-induced expression of the inducible gene zenk has generated novel insights on the functional organization of the brain pathways that control perceptual and motor aspects of vocal communication in birds. On-going molecular studies on the function of zenk and other inducible genes in songbirds and mammals should help reveal the significance of inducible gene expression for neuronal function and plasticity, and for the laying-down and maintenance of behaviorally relevant memories.

\section{RESUMO}

O gene imediato zenk é um gene dependente de atividade que é marcadamente induzido em áreas cerebrais de processamento auditivo ou de controle vocal motor quando pássaros ouvem ou produzem canto, respectivamente. Estudos da expressão de zenk em pássaros canoros e outros grupos de aves será revisto neste artigo, enfocando como esta análise tem gerado novas perspectivas no entendimento das vias e mecanismos envolvidos em aspectos perceptuais e motores da comunicação e do aprendizado vocais.

Palavras-chave: zenk, pássaros canoros, processamento auditivo, aprendizado, canto.

\section{REFERENCES}

Bolhuis JJ, Zijlstra GG, DEN Boer-Visser AM AND VAN DER ZEE EA. 2000. Localized neuronal activation in the Zebra Finch brain is related to the strength of song learning. Proc Natl Acad Sci 97: 22822285.

Bottjer SW, Miesner EA AND Arnold AP. 1984. Forebrain lesions disrupt development but not maintenance of song in passerine birds. Science 224: 901-903.

Brenowitz EA, Margoliash D and Nordeen KW. 1997. The neurobiology of birdsong. J Neurobiol 33 (special issue).

Chew SJ, Mello C, Nottebohm F, Jarvis E and VICARIO DS. 1995. Decrements in auditory responses to a repeated conspecific song are long-lasting and require two periods of protein synthesis in the songbird forebrain. Proc Natl Acad Sci 92: 3406-3410.

Guzowski JF, LyFord GL, Stevenson GD, Houston FP, McGaugh JL, Worley PF and Barnes CA. 2000. Inhibition of activity-dependent arc protein expression in the rat hippocampus impairs the maintenance of long-term potentiation and the consolidation of long-term memory. J Neurosci 20 : 3993-4001.

JARVis ED AND Mello CV. 2000. Molecular mapping of brain areas involved in parrot vocal communication. J Comp Neurol 419: 1-31. 
JARVis ED AND NotTEBOHм F. 1997. Motor-driven gene expression. Proc Natl Acad Sci 94: 4097-4102.

Jarvis ED, Schwabl H, Ribeiro S and Mello CV. 1997. Brain gene regulation by territorial singing behavior in freely ranging songbirds. Neuroreport 8: 2073-2077.

Jarvis ED, ScharfF C, GRossman MR, Ramos JA AND Notтевонм F. 1998. For whom the bird sings: context-dependent gene expression. Neuron 21: 775-788.

Jarvis ED, Ribeiro S, Silva ML, Ventura D, VielLIARD J AND MELlo CV. 2000. Behaviourally driven gene expression reveals song nuclei in hummingbird brain. Nature 406: 628-632.

Jin H AND Clayton DF. 1997. Localized changes in immediate-early gene regulation during sensory and motor learning in Zebra Finches. Neuron 19: 1049 1059.

Jones MW, Errington ML, French PJ, Fine A, Bliss TV, Garel S, Charnay P, Bozon B, Laroche S AND DAVIS S. 2001. A requirement for the immediate early gene Zif268 in the expression of late LTP and long-term memories. Nature Neurosci 4: 289-296.

Kaczmarek L and Robertson HA. 2002. Immediate early genes and inducible transcription factors in mapping of the central nervous system function and dysfunction. Amsterdam: Elsevier.

Karten HJ and Shimizu T. 1989. The origins of neocortex: connections and lamination as distinct events in evolution. J Cogn Neurosci 1: 291-301.

Mello CV. 1998. Auditory experience, gene regulation and auditory memories in songbirds. J Braz Assoc Adv Sci 50: 189-196.

Mello CV. 2002. Mapping vocal communication pathways in birds with inducible gene expression. J Comp Physiol A 188: 943-959.
Mello CV and Clayton DF. 1994. Song-induced ZENK gene expression in auditory pathways of songbird brain and its relation to the song control system. J Neurosci 14: 6652-6666.

Mello CV, Vicario DS and Clayton DF. 1992. Song presentation induces gene expression in the songbird forebrain. Proc Natl Acad Sci 89: 6818-6822.

Mello CV, Vates GE, Okuhata S and Nottebohm F. 1998. Descending auditory pathways in the adult male Zebra Finch (Taeniopygia guttata). J Comp Neurol 395: 137-160.

Morgan JI AND Curran T. 1989. Stimulustranscription coupling in neurons: role of cellular immediate-early genes. TINS 12: 459-462.

Ribeiro S, Cecchi GA, Magnasco MO and Mello CV. 1998. Toward a song code: evidence for a syllabic representation in the canary brain. Neuron 21: 359-371.

ScharfF C and Nottebohm F. 1991. A comparative study of the behavioral deficits following lesions of various parts of the Zebra Finch song system: Implications for vocal learning. J Neurosci 11: 2896-2913.

Sheng M And Greenberg ME. 1990. The regulation and function of c-fos and other immediate early genes in the nervous system. Neuron 4: 477-485.

Stripling R, Volman SF and Clayton DF. 1997. Response modulation in the Zebra Finch neostriatum: relationship to nuclear gene regulation. J Neurosci 17: 3883-3893.

Vates GE, Broome BM, Mello CV and Nottebohm F. 1996. Auditory pathways of caudal telencephalon and their relation to the song system of adult male Zebra Finches. J Comp Neurol 366: 613-642. 